DOI

\title{
ПИТАННЯ РОЗРОБКИ ОСВІТНІХ СТАНДАРТІВ ПІДГОТОВКИ ФАХІВЦІВ У ЛІКАРСЬКІЙ РЕЗИДЕНТУРІ
}

\author{
Ю. В. Вороненко, Ю. П. Вдовиченко, О. К. Толстанов, Р. О. Мойсеєнко, \\ О. М. Вернер, В. В. Краснов
}

Національна медична академія післядипломної освіти імені П. Л. Шупика

\section{ISSUE OF EDUCATIONAL STANDARDS DEVELOPMENT FOR TRAINING SPECIALISTS IN DOCTOR RESIDENCY}

\author{
Yu. V. Voronenko, Yu. P. Vdovychenko, O. K. Tolstanov, R. O. Moiseyenko, \\ O. M. Werner, V. V. Krasnov \\ Shupyk National Medical Academy of Postgraduate Education
}

\begin{abstract}
Закон України “Про вищу освіту” ввів нову форму післядипломної освіти - лікарську резидентуру. Підготовка фахівців повинна відбуватися за освітньюю програмою, але для резидентури Закон зазначив програму післядипломної освіти. У зв'язку з тим виникла проблема - на даний момент немає вимог до формату та змісту програми навчання в лікарській резидентурі. Показано неузгодженість між вимогами Закону України “Про вищу освіту” та традиційною системою підготовки медичних кадрів. На основі аналізу вимог до освітньої програми, пропозицій Всесвітньої федерації медичної освіти та різних програм підготовки в лікарській резидентурі Європи та інших країн у статті запропоновано проект типової програми післядипломної освіти для підготовки лікарів-резидентів в Україні. Запропоновано такі складові типової програми, як: мета та результати навчання для слухачів і керівників; електронне портфоліо для моніторингу результатів; самоаналіз і самооцінка; вимоги до навчальних закладів; вимоги до керівництва підготовкою лікаря-резидента; вимоги до клінічної бази кафедри; побудова проекту і принципи його оцінювання; ставлення, поведінка, особистісні характеристики лікаря-резидента. Зроблений висновок про необхідність побудови двокомпонентного стандарту вищої медичної освіти з компетентнісними моделями випускника магістратури та інтернатури.
\end{abstract}

Ukrainian law “On higher education” has implemented a new form of postgraduate education - doctor residency. Specialists' training must follow the educational program, but according to this law residency must follow the postgraduate educational program. For this reason we have the next problem - there are no requirements to program's content and form at the moment. There is non-compliance between Ukrainian higher education law and traditional system of medical specialists training. According to the analysis of requirements to educational program, International Federation of medical education offerings and different residency programs in Europe and other countries, the project of typical postgraduate educational program for training doctors in Ukraine is proposed in this article. We offer such elements of this typical program as: aim and results of studying for listeners and heads; electronic portfolio for results monitoring; self check and self estimation; requirements to educational institutions; requirements to heads in resident-doctors trainings; requirements to department's clinical base; project construction and principles of its estimation; attitude; behavior; personal characteristics of resident-doctor. We have come to a conclusion that it is necessary to construct a two-component standard in higher medical education including competency models for graduates of internship and magistracy.

Вступ. Забезпечення високих стандартів допомоги пацієнтам шляхом створення якісних освітніх програм є надзвичайно важливим завданням післядипломної медичної освіти [1].

Система підготовки медичних кадрів у всьому світі має свою специфіку, що відрізняє ії від інших професійних спрямувань. Одна з основних відмінностей полягає у тому, що після завершення додипломної фази підготовки дипломований лікар не має можливості здійснювати професійну діяль-

( Ю. В. Вороненко, Ю. П. Вдовиченко, О. К. Толстанов та ін. ність, а повинен пройти обов'язкову фазу первинної спеціалізації, що здійснюється в системі післядипломної освіти. В Україні традиційно первинна спеціалізація проходить у формі інтернатури. Законодавча база цієї форми навчання достатньо добре відпрацьована за довгі роки її існування.

Закон України “Про вищу освіту” (далі - Закон “Про ВО”), що набув чинності у 2014 р., ввів нову форму післядипломної освіти - лікарську резидентуру, яка “...є формою спеціалізації лікарівспеціалістів за певними лікарськими спеціальнос- 
тями виключно на відповідних клінічних кафедрах для отримання кваліфікації лікаря-спеціаліста згідно з переліком лікарських спеціальностей...”. Навчання в лікарській резидентурі повинно проходити за “програмою післядипломної освіти” 3 подальшим отриманням відповідного документа [2]. Однак регламентуюча законодавча база забезпечення освітнього процесу в лікарській резидентурі ще не $є$ достатньо відпрацьованою. Окрім того, можна побачити деяку неузгодженість між вимогами Закону України “Про ВО” та традиційно сформованою системою функціонування освітнього процесу при підготовці медичних кадрів. Цю неузгодженість, яка вимагає додаткового роз'яснення саме для організації навчання в лікарській резидентурі, можна представити такими результатами аналізу:

1) підготовка фахівців повинна проходити за освітньою програмою, але п. 9 Закону “Про ВО” зазначає необхідність проходження резидентами програми післядипломної освіти;

2) не визначені відповідальні за розробку освітніх програм;

3) освітня програма - це “система освітніх компонентів на відповідному рівні вищої освіти...”, але регламентацію післядипломної освіти виведено за поле рівнів вищої освіти. Таким чином, незрозуміло, чи повинні розповсюджуватися вимоги до структури освітньої програми на вимоги до розробки програми післядипломної освіти;

4) стандарт вищої освіти являє собою “сукупність вимог ... за кожним рівнем вищої освіти...”. Поняття “рівні вищої освіти” не розповсюджується на післядипломний етап. 3 такого аналізу виходить, що Стандарти для післядипломної освіти розроблятися не повинні;

5) освітня програма повинна бути акредитована. При акредитації перевіряється відповідність цієї програми вимогам стандарту вищої освіти. Як зазначалося вище, стандарт вищої освіти не передбачається для післядипломного рівня. Виходячи 3 наведених позицій, Закон “Про ВО” не передбачає акредитацію програми післядипломної освіти.

Таким чином, наявна проблема, що стосується питання розробки такої програми підготовки лікаря-резидента, яка б не порушувала Закон України “Про ВО” та задовольняла специфічні вимоги системи післядипломної освіти.

Мета - розробити модель програми післядипломної освіти для підготовки лікаря-резидента, яка б була гармонізована з вимогами до фахівців, які переходять $з$ додипломного етапу навчання, та відповідала аналогам у розвинених країнах світу.

Основна частина. У своїй роботі ми використовували три джерела вимог до структури та змісту освітніх програм: 1) Закон України “Про вищу освіту”; 2) вимоги Всесвітньої федерації медичної освіти (WFME), що зазначені у стандарті післядипломної освіти; 3) моделі програм підготовки лікарів-резидентів, що підтверджені Європейською спілкою медичних фахівців (UEMS) і Європейською конфедерацією педіатрів (CESP).

Стандарт вищої освіти (п. 3 статті 10, розділу III Закону “Про ВО”) визначає такі складові освітньої програми:

1) обсяг кредитів ЄКТС, необхідний для здобуття відповідного ступеня вищої освіти;

2) перелік компетентностей випускника;

3) нормативний зміст підготовки здобувачів вищої освіти, сформульований у термінах результатів навчання;

4) форми атестації здобувачів вищої освіти;

5) вимоги до наявності системи внутрішнього забезпечення якості вищої освіти;

6) вимоги професійних стандартів (у разі їх наявності).

Серед перелічених компонентів тільки необхідність визначення кредитів ЄКТС не може бути застосована до післядипломної освіти, оскільки вимоги Болонського процесу є прерогативою суто додипломного етапу.

Стандарт післядипломної освіти WFME у рубриках, у яких зазначаються зміст та кінцеві результати підготовки [1], пропонує ввести такі компетенції до програм навчання лікарів-резидентів: 1) навички роботи в команді з професіоналами охорони здоров'я, науковим співтовариством і громадськістю; 2) здатність оцінювати і застосовувати нові наукові знання для постійного поліпшення клінічної практики; 3) виконання функції керівника, інструктора і педагога по відношенню до колег, студентів-медиків та інших медичних працівників; 4) внесення вкладу в розвиток науки; 5) мотивація i здатність діяти в якості захисника пацієнта; 6) здатність розуміти охорону здоров'я, а також ідентифікувати потребу і проводити системні заходи щодо поліпшення медичної допомоги. Однією з основних вимог до результатів навчання у лікарській резидентурі $є$ набуття компетенцій спілкування та прийняття клінічних рішень. 
Як зазначено у стандарті WFME, ці компетенції повинні набуватися лікарями-резидентами у рамках таких дисциплін, як: базисні медичні, клінічні, поведінкові та соціальні науки; медична етика; суспільна охорона здоров’я; медична юриспруденція; управлінські дисципліни тощо.

Ще одна з вимог стандарту WFME: із заданою періодичністю повинні проводитися корекція та адаптація кінцевих результатів навчання залежно від розвитку суспільства, медичної науки та потреб середовища, де працюватиме лікар. Все це висуває вимоги і до самої організації навчального процесу на базах та кафедрі з постійною адаптацією навчальних підходів і методів підготовки, з періодичним удосконаленням процесу моніторингу, оцінкою програми та результатів підготовки.

На основі зроблених аналітичних висновків робочою групою НМАПО імені П. Л. Шупика було запропоновано структурно-функціональну модель програми підготовки лікаря-резидента. Нижче представлені основні складові цієї моделі.

У програмі повинні бути зазначені мета та результати у вигляді компетенцій, яких необхідно досягти під час навчання у резидентурі як самим слухачам, так і керівникам при організації освітнього процесу.

Необхідно формалізувати систему підтвердження процесу та результату освітньої діяльності лікарярезидента у вигляді електронного портфоліо, що демонструватиме прогрес у формуванні компетенцій.

Важливо зазначати тривалість та специфіку навчання з урахуванням зовнішніх медичних підрозділів (відділень), які даватимуть змогу отримувати специфічні навички, недоступні в основному навчальному закладі (відділенні).

Моніторинг якості досягнутих результатів навчання необхідно засновувати на основі процесів самоаналізу і самооцінки з подальшою фіксацією в електронному портфоліо.

Обов'язково чітко зазначати вимоги до навчальних закладів, що отримуватимуть право на підготовку лікаря-резидента; вимоги до керівництва підготовкою лікаря-резидента, до його функцій, досвіду, статусу та стажу, самовдосконалення; вимоги до клінічної бази кафедри, що забезпечує підготовку лікаря-резидента. До останньої складової входять: персонал, обладнання, частота вирішення професійних завдань, розвиненість системи забез- печення якості процесу та результату медичної діяльності клінічного закладу тощо.

Необхідно грунтовно прописати вимоги до проекту, який повинен продемонструвати здатність лікаря-резидента готувати наукові клінічні роботи, здійснювати аналіз клінічної практики, розробляти самі проекти. Також важливо виокремити опис процесів оцінювання підготовлених проектів та критерії їх якості.

Окремим блоком у програмі необхідно зазначити ставлення та поведінку при роботі з колегами, з пацієнтами та їхніми родинами, особистісні характеристики лікаря-резидента.

Запропонована модель знайшла практичне втілення при розробці стандарту підготовки лікарярезидента за спеціальністю “Неонатологія”, що проходило під егідою Україно-Швейцарської програми “Здоров’я матері та дитини” [3].

Вважаємо, що в Законі України “Про ВО” недостатньо врахована специфіка двохетапної підготовки медичних кадрів. Одна з основних проблем полягає у тому, що “стандарти вищої освіти розробляються для кожного рівня вищої освіти в межах кожної спеціальності відповідно до Національної рамки кваліфікацій ...” (п. 2 статті 10, розділу III Закону “Про ВО”). У свою чергу, “Національна рамка кваліфікацій спрямована на введення європейських стандартів та принципів забезпечення якості освіти з урахуванням вимог ринку праці до компетентностей фахівців” (частина “в”, підпункту 2, пункту 4, розділу XV Закону “Про ВО”). Тобто стандарт вищої освіти повинен будуватися з урахуванням вимог ринку та роботодавця. Але в медичній освіті у випускника магістратури ще немає повноцінного ринку праці, який готовий надати йому роботу, оскільки споживачем “продукту” магістратури $є$ наступний етап навчання - інтернатура.

Висновки. Ми вважаємо, що повноцінний стандарт вищої медичної освіти має містити модель випускника саме з інтернатури, представлену у вигляді результатів навчання (компетенцій). Вимоги до підготовки в магістратурі повинні бути тільки складовою такого стандарту. Подібна модель повинна бути гармонізована з регламентуючими документами щодо підготовки лікарярезидента. Тільки в такому випадку ми зможемо отримати діючу, сучасну, європейську систему підготовки медичних кадрів з урахуванням вимог основних споживачів такої системи - медичного ринку праці. 


\section{Список літератури}

1. World Federation for Medical Education. Global standards for quality improvement. Postgraduate Medical Education. WFME 2003. - Режим доступу : http:// wfme.org/standards/pgme/20-quality-improvement-inpostgraduate-medical-education-russian/file.

2. Закон України “Про вищу освіту”[Електронний ресурс] / Верховна Рада України; Закон від 01.07.2014 р. № 1556-VII. - Режим доступу URL : http://zakon4.rada. gov.ua/laws/show/1556-18.
3. Принципи розробки освітнього стандарту підготовки фахівців в лікарській резидентурі (на прикладі спеціальності “Неонатологія”). Методичні рекомендації [Електронний ресурс] / [Є. Є. Шунько, Д. О. Добрянський, В. В. Краснов та ін.]. - К., 2015. - 47 с. - Режим доступу URL : http://motherandchild.org.ua/files/attachments/ Guidelines_residency_curriculum.pdf. 